\title{
船体外板の亜鉊による陰極防食試験*1
}

重野隼太*2 清原宗遠*3 倉成喬*4

\section{Long-Term Tests on Cathodic Protection of a Ship-Hull with Zinc and Zine Alloy Anodes.}

\section{Hayata Shigeno, Munetô Kiyohara and Takashi Kuranari}

A series of successive tests on cathodic protection of ship-hull of a small sea-going ship were carried out with a period of each one year since 1955.

In each case the kind and quantity of zinc or zinc alloy anode were varied to determine the criteria for installation. Hull potentials and anode currents of zinc were measured periodically and those in the running condition were also measured.

The results obtained were as follows:

(1) Zn-Al alloy anode showed excellent perform-

\section{1. 前}

海洋を航行する鋼船の船尾には古くから防食の目的で 少量の亜鉛板が装着されてきたが，近年亜鉛による陰極 防食の理念が著しく発展するにつれて, 船嚾外板没水部 に抢ける亜鉛板の陽極性能抢よび防食㕮果を明確にする 必要性が痛感されるに至った。われわれは涬い三井鉱山 株式会社の協力により昭和 30 年以降長期にわたる実船 試験を開始する機会を得た。供試船は三池港務所所属の 三池丸(総屯数 $146 \mathrm{t}$ ) で, 昭和 17 年玉野造船所におい て建造後, 曳船として長年就航したものであるが，昭和 30 年 6 月以来約 1 力年ごとに成績を調べる方法によりす でに 4 回の試験を終了し，現在第 5 回目の試験を続行し ている。符 1 期の試験は当時最初の試みとして亜鉛によ る船体の全面防食を計画するとともに，呙純度亜鉛の実 用試験を洋水て行なわれたが，第 2 および第 3 期試験は 亜鉛所要取付個数決定のため装凅量を種々に変えて実施 し，また第 3 および第 4 期試験は実船における各種 Zn$\mathrm{Al}$ 合金の性能を確認する目的で行なわれた。本報にお いては紙数の関係上第 3〜4 期試験を主として記述する こととする。

\section{2. 試 験 要 領}

試験対象船舶：三池丸の船体は長さ $24 \mathrm{~m}$, 幅 $7 \mathrm{~m}$,

*1 昭和 33 年 11 月 18 日第 2 回防食技術研究討論会において一部を発 表

*2 東京工業試験所第 6 部（東京都目黒区中目黑 1 の 58)

*3 三井金属鉱業(株)三池製煉所 (大轩田市浅车田町)

*4三井金属鉱業(株)製煉部（東京都中央区日本橋室町 2 の 1 ) ance as compared with high purity zinc so far as ship hull protection is concerned.

(2) The ship hull is substantially protected from corrosion so far as the hull potential in stagnant sea water was maintained below the so-called protective potential, $-770 \mathrm{mV}$ referred to saturated calomel electrode.

(3) In the case of ship tested, an adequate quantity of zinc alloy anodes can be determined in such a way that the ratio of total anode area to immersed area of ship hull is greater than $1 / 200$.

吃水 $3.35 \mathrm{~m}$, 浸水面績 $215 \mathrm{~m}^{2}$ で，船底には下歭りに シルバックス，上塗りにフェノールレジン十乾性油のラ ジンベンを塗装しており，マンガン青銅製プロペラ 2 個

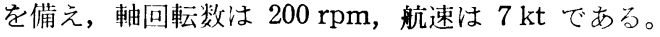

第 1 表 供試亜鉛陽極の組成

\begin{tabular}{|c|c|c|c|c|c|c|c|}
\hline \multirow{2}{*}{ 期 } & \multirow{2}{*}{ 別 } & \multirow{2}{*}{ 材 } & \multicolumn{2}{|r|}{ 分 } & \multicolumn{2}{|c|}{ 值 $\mathrm{ppm}$} & \multirow[b]{2}{*}{ Al } \\
\hline & & & $\mathrm{Fe}$ & \multirow{2}{*}{${ }_{19}^{C}$} & $\mathrm{~Pb}$ & $\mathrm{Cd}$ & \\
\hline \multirow{8}{*}{$\begin{array}{l}\text { 3, } \\
3 \text {, }\end{array}$} & 列 & & \multirow{8}{*}{$\begin{array}{r}58 \\
39 \\
2 \\
150 \\
160 \\
4 \\
4 \\
12\end{array}$} & & 23 & 11 & $\ldots$ \\
\hline & \multirow{2}{*}{$\begin{array}{l}1 \\
2 \\
3\end{array}$} & $\mathrm{Zn}_{\mathrm{n}}$ & & 6 & 26 & 9 & - \\
\hline & & \multirow{6}{*}{$\begin{array}{c}\mathrm{VZ}+0.2 \mathrm{Al} \\
=0.5 \mathrm{Al} \\
\mathrm{Zn}_{\mathrm{n}}+0.1 \mathrm{Al} \\
+0.2 \mathrm{Al} \\
\mathrm{Zn}+\mathrm{Cd}\end{array}$} & & 5 & 19 & 3 & $<10$ \\
\hline & \multirow{5}{*}{$\begin{array}{l}1 \\
2 \\
3 \\
4 \\
4 \\
4 \\
4 \\
4\end{array}$} & & & 18 & 1,620 & 960 & 1,700 \\
\hline & & & & 17 & 1,490 & 900 & 5,100 \\
\hline & & & & 4 & 17 & 3 & 1,000 \\
\hline & & & & 4 & 17 & & 2,100 \\
\hline & & & & 5 & 16 & 1,070 & \\
\hline
\end{tabular}

供試亜鉛板：第 1 表に示す組成をもつ純亜鉛なた注亜 鉛合金（A1 または Cd 添加）の鋳造陽極（裏面ゴムシー 卜張り）を用い，内祁に䤻込えだ鉄芯を外板に溶接して 船殻に取付けた。船体における取付け配置の概況を第 1 図に示す。

亜鉛の装篔量：第 2 表に装着した亜鉛の材質・個数等 を総括して示す。装着量については当初データに汇し

取付け時期

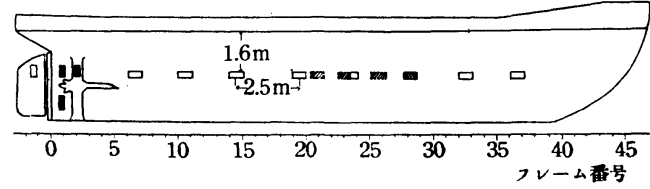

配置は両䑤対称, 第 1 期は各䑤フレーム No. $1 \sim 5$ に 6 伿, No. 20 〜1 に 8 個を装着

第 1 図船体における亜鉛陽極の配置 
第 2 表 期別の亜鉛陽極装着量

\begin{tabular}{|c|c|c|c|c|}
\hline 师間 & 使 用 亜 鉛 板 & 倜 数 & $\begin{array}{c}\text { 総面皘 } \\
\text { m }^{2}\end{array}$ & $\begin{array}{l}\text { 対漫水 } \\
\text { 面積比 }\end{array}$ \\
\hline $1 !\left(\begin{array}{lll}30 . & 6 . & 22 \\
31 . & 6 . & 25 \\
\end{array}\right.$ & $\begin{array}{c}\mathrm{Zn} \\
(600 \times 150 \times 30 \mathrm{~mm})\end{array}$ & 28 & 2.52 & 86 \\
\hline 2 期 $\left(\begin{array}{lll}31 . & 6 . & 25 \\
32 . & 6 . & 30\end{array}\right.$ & $\left(\begin{array}{c}\mathrm{Zn} \\
(300 \times 150 \times 25 \mathrm{~mm})\end{array}\right.$ & 1 & 0.63 & 341 \\
\hline 3 期 $\left(\begin{array}{lll}32 . & 6 . & 30 \\
33 . & 6 . & 30\end{array}\right.$ & $\begin{array}{c}\mathrm{Zn} \\
\mathrm{VZ}+0.2 \mathrm{Al} \\
\mathrm{VZ}+0.5 \mathrm{Al} \\
(300 \times 150 \times 20 \mathrm{~mm})\end{array}$ & 船尾 & 1.08 & 199 \\
\hline 4 约 $\left(\begin{array}{lll}33 . & 6 . & 30 \\
34 . & 6 . & 27\end{array}\right.$ & $\begin{array}{c}\mathrm{Zn}+0.1 \mathrm{Al} \\
\mathrm{Zn}+0.2 \mathrm{Al} \\
\mathrm{VZ}+0.2 \mathrm{Al} \\
\mathrm{VZ}+0.5 \mathrm{Al} \\
\mathrm{Zn}+\mathrm{Cd} \\
(300 \times 150 \times 20 \mathrm{~mm})\end{array}$ & $\begin{array}{l}\text { 右舷 } \\
\text { 左䑨 } \\
\text { " 船首 }\end{array}$ & 1.08 & 199 \\
\hline
\end{tabular}

（注） $\mathbf{Z n}=$ 電父亜鉊または高純度亜鉊 $\quad \mathrm{V} \mathbf{Z}=$ 竪型蒸留亜鉊

く，ことに籍 1 斯試験に打いては浸水面皘 $1 \mathrm{~m}^{2}$ につき $20 \mathrm{~mA}$ と仮定して $215 \mathrm{~m}^{2}$ の船該に対し $4.3 \mathrm{~A}$, さら に完全防食を期してプロペラ $4.5 \mathrm{~m}^{2}$ に対し $3 \mathrm{~A}$ を追 加，们計 $7.3 \mathrm{~A}$ を供給する計画とし，また亜鉛の陽極 電流密没を $3 \mathrm{~A} / \mathrm{m}^{2}$ と推定した。彷って亜鉛の所要面 䅪汢約 $2.5 \mathrm{~m}^{2}$ となり, $600 \times 150 \times 30 \mathrm{~mm}$ の亜鉛板 28 枚を使用したが，陚験の結果取付量は過大と認められ た。符 2 期試験で汸前期に比し亜鉛の取付量を大幅に減 らすこととし， $300 \times 150 \times 25 \mathrm{~mm}$ の亜鉛 14 枚を装着し た。これは当時船尾部防食を主眼とする米海軍推奖の亜 鉛板炆付基準を船体外板全部に拡张適用した個数に相当 する*。その絬果は取付量が不足と㤎められた。

筑 3 搏試験の場会注改訂された米国海軍规格 MIL-A18001 B に準じ，船体面积の $1 / 200$ およよ゙゙プロペラ面稜 の $1 / 15$ の和に相当する $1.38 \mathrm{~m}^{2}$ の表面皘を有する亜 鉛を取付けることとし，隄㥛板の側面積も考虑に入れ $300 \times 150 \times 20 \mathrm{~mm}$ の亜鉛また流鉛介金板 24 枚を装算 した。第 4 期試験も節 3 期と同量を取付けた。

亜鉛晹㥛：西鉛汢平板状の芯金溶接式鋳造陽極を俅用 し，その财質は当初純西鉛のみ用い，第 3 期以降は比較 のため雨鉛合金を主として用いた。

船体電位の測定：各期間とも $1 \sim 3$ 力月の間隔で三池 港閘閒外飞慗留時の船体電仙を測定した。計測には当初 は Beckman 社または島津製の真空管式 $\mathrm{pH}$ 計, その 後注束洋理化製の具空管電位差計を用い，随時カドミウ ム標準電池で較正して正確を期した。照合電極としては 飽和 $\mathrm{KCl}$ 甘录電極 (S.C.E.) を使用した。両舷 60 余 個所に抢いて深さをほぼ 3 段に变えた約 200 の測定点 の活， 5 個所に抢いて船体横断面に沿い $1 \mathrm{~m}$ 問隔で 電位測定を行なった。航走時に抢ける船体電位は籍 4 期 試験の際に测定した。これには來京工業試験所で試作し た海水甘承電極を船尾加後方約 $40 \mathrm{~m}$ の距離に电行 し,これと船体との間の電位差を真空管電位差浢（東泽

* 米游軍推奖の亜鉊板 $(300 \times 150 \mathrm{~mm})$ の取付数はプロペラ 1 個を有 する船の場合 $\mathrm{S} \times 0.15 \times 0.003 / 0.5=0.0009 \mathrm{~S}$ で示される。ここで $\mathrm{S}$ は外板の漫水面積 $\left(\mathrm{ft}^{2}\right), 0.003$ は所要陰極電流密度 $\left(\mathrm{A} / \mathrm{ft}^{2}\right)$, 0.5 は亜鉊 1 個当り発生電流 (A) を意味する。2 軸の船では上式 の值の 1.5 倍, 4 軸の場合は 2 倍とすることになっている。

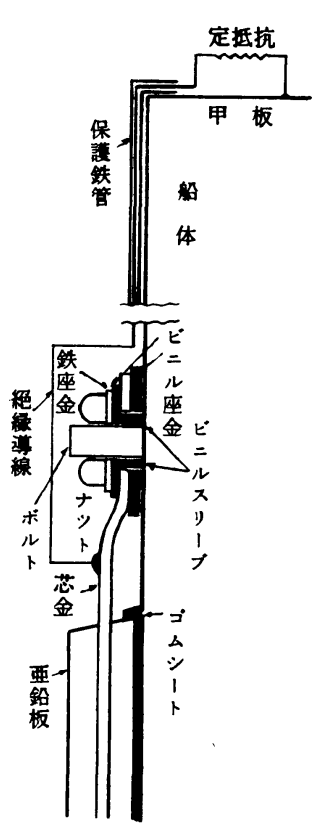

第 2 図陽極発生電流 测定装置

底叙膜の状態を観察した。

\section{3. 試験結果とその考察}

\section{(1) 船体電位}

本船の試駼開始直前における電位法各部とる均一で 645〜655 mV (S. C. E.) の範囲にあった。当時船尾およ び舵蔀に少量のボイラージンクが取付けられていたが, 有效に作用していないように胃えた。第 1 期試験に入り 浸水 3 日後の测定で注電位はすでに各部とも $-830 \mathrm{mV}$ 以下に分極したが，亜鉛の近傍は $-960 \mathrm{mV}$ にまで達 した。これ注业鉛が船尾部（フレーム No. 1〜5)に 12 個抢よび中央部（フレームNo. 20〜31）に 16 個と集中 して取付けられているためである。その後の電位経過は 水域打よび吃水の影響を受けて上下したが，全体として 時口とともに濑次上昇の傾向をたどり，阙始後 7 力月以 降は上昇傾向が古まった。これは亜鉛の表面に漸次不溶 性の被膜を形成した結果と考えられるが，装着量にかな りの余裕があるため終末の 348 日目においてもほぼ防食 電佁 $-770 \mathrm{mV}$ を保持した。なお計測の際の停泊地付近 の敏水の $\mathrm{pH}$ は $7.8 \sim 7.9$, 比抵抗は $22 \sim 24 \Omega \cdot \mathrm{cm}$ で あった。

次に第 2 期試験においては亜鉛板を船尾のフレーム No. 0 および No. 2 に 3 個，フレーム No. 20〜29 の間 に 4 個, 両舷で 14 個に減らしたため, 電位は当初 -820 $\sim 880 \mathrm{mV}$ を示したものの, 終末には $-600 \mathrm{mV}$ 内外 にまで上昇した。これは亜鉛の装着量が不足のうえその

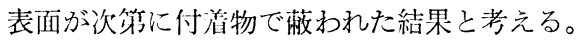

第 3 期試験においては亜鉛注船尾に 4 個のほかフレー 
ム No. 7〜38 に 8 個, 両舷で 24 個と装着量を増し, 均 等に分散して配置し，同時に高性能の合金陽極を多く使 用した。その結果，電位は当初 $-830 \sim 900 \mathrm{mV}$, 終末 には $-750 〜 860 \mathrm{mV}$ という良好な成績を示した。ただ し高純度亜鉛を取付けてある船尾部の電位が終末頃やや 上昇した。

第 4 期試験湔期と同数の亜鉛合金陽極を取付けた結 果, 当初-900〜950mV, 終末で $-820 \sim 900 \mathrm{mV}$ という 優良な

電位を

保持し

船首か ら船尾 までき わめて 均一な

電位分

布を示

した。

各期の

試験に

おける

開始当

初と終

了直前

の船体

電位分

布を第

3 図に

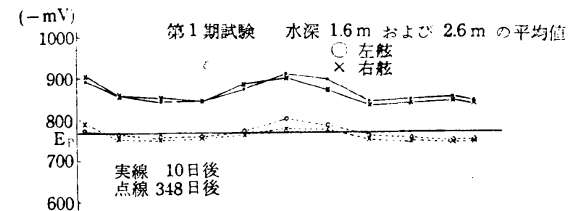

示す。

陽極の

総面積

におい

七第 1

期の43

\%に過

ぎない

第 4 期

の場合

船体電

位が第

1 期よ

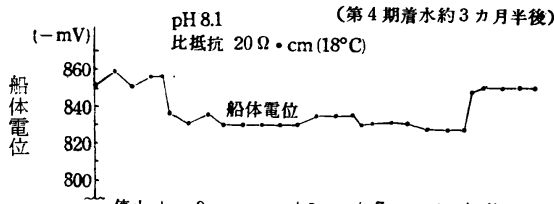

りもは 第 4 図 航走時における船体電位と発生電流

るかに低電位を保持しているが，これは高純度覀鉛に対 比して Al 添加亜鉛合金の性能がすぐれていることを示 している。

航走時の船体電位測定は第 4 期試験開始 3.5 力.日後に
有明海において実施した。第 4 図に示す通り航走時の電 位は停止時に比し約 $20 \mathrm{mV}$ の上昇を示したが，航速の 変化による電位变化はあまり認めら机なかった。なお本 測定のように基準電極を曳行した場合と船尾直下に近づ けた場合との測定值の差異を停止中に実測した絬果，前 者が約 $20 \mathrm{mV}$ 負㢟を示すことを確かめた。

\section{（2）覀鉛の発生電流}

第 4 期試験においては右舷の $\mathrm{Zn}+0.2 \mathrm{Al}$ 陽極少よび 左舷の $\mathrm{VZ}+0.5 \mathrm{Al}$ 陽極の各 1 個について発生電流を 実測した。静止時における発生電流は両陽極とも大差な く, 船体電位 $-840 \sim 935 \mathrm{mV}$ において 0.18〜0.28 A 徉 って陽極電流密度は $4 \sim 6 \mathrm{~A} / \mathrm{m}^{2}$ の範囲にあった。

航走時における発生電流は航速とともに增す傾向が認 められるが，時速約 $7 \mathrm{kt}$ の場合静止時に比し $10 \%$ 程 度の増加に過ぎない。第 4 図に見られるとおり, $\mathrm{Zn}+$ $0.2 \mathrm{Al}$ に比べ $\mathrm{VZ}+0.5 \mathrm{Al}$ の発生電流の方が $50 \%$ 程 度大きい。いま亜鉛板を半球陽極と考元，同心の半球陰 極との間の接地抵抗計算式に基づいて，业鉛陽極の接地 抵抗を推算すると $\quad \mathrm{R}=\rho / 2 \pi \mathrm{r}=\rho / 2.5 \sqrt{\mathrm{S}}$

$\rho$ は海水比抵抗で $20 \Omega \cdot \mathrm{cm}, \mathrm{s}$ は陽極表面積で 450 $\mathrm{cm}^{2}$ とすれば $\mathrm{R}=0.38 \Omega$

第 4 図により船体電位 $\mathrm{E}_{\mathrm{c}}$ は $-0.83 \mathrm{~V}$, 西鉛の陽極 電位 $\mathrm{E}_{\mathrm{a}}$ は $-1.0 \mathrm{~V}$ とすれば，覀鉛の発生電流は $\mathrm{I}=$ $\left(\mathrm{E}_{\mathrm{c}}-\mathrm{E}_{\mathrm{a}}\right) / \mathrm{R}=0.45 \mathrm{~A}$ と算出される。実測值は $\mathrm{VZ}+0.5$ $\mathrm{Al}$ の陽極 $0.34 \mathrm{~A}$ 程度, $\mathrm{Zn}+0.2 \mathrm{Al}$ では $0.23 \mathrm{~A}$ 程度 に過ぎないが，この差異を生じた原因としては計算で無 視した亜鉛表面の皮膜抵抗，海水中の抵抗などの回路抵 抗のほか，接地抵抗計算式に使用した陽極表面積の算定 と隣接陽極による影響などが考えられる。

\section{(3) 船体の状況}

試験後上架の際の船体の観察維果を概括すると次のご とくである。

第 1 期：錆の発生はほとえどなく，塗膜が当初から残 存した錆とともに浮上った部分がある。生物の付着はほ とえどない。

第 2 期：錆が各所に散見され，塗膜が諸所で鋓離し発 錆している。試験塗装のビニル系塗膜は異常がない。生 物の付着はほとんどない。

第 3 期：吃水部を除き発錆はない。塗膜は船底部で広 範囲に浮上りを生じたが，供試ビニル塗装は異 常がな い。生物の付着はきわめて少ない。

第 4 期：吃水部を除き発錆はない。塗膜は一部䡈離し たが比較的良好で船底部も異常がない。吃水部の試験塗 装（WP 1，ビニル AC 5, AF 2) は全く異常がない。 生物は僅少である。

船体の防食状況は船体電位が防食電位を下回った第 2 期を除きおお主ね良好であった。 
塗装に対する影響は，亜鉛を過剩に取付けた場合で も，健全な塗装について注一般に軽微といえるが，涩膜 の状態の不良なものは涂離する傾向を生じた。

貝類, 藻類など生物に対する効果は判然としない。

\section{（4） 陽極要鉛の溶解状況と溶解量}

試験終了時における陽極の溶解性および付着物の状沉 は次のごとくである。

第 1 期：高純度西鉛注原形を保持し, 硬質の灰色生成 物で被覆されていた。

第 2 期：高純度要鉛は厚い灰白色付着物で蔽われ，凹 凸の多い溶解性を示した。付着物は水酸化亜鉛のほか分 析の結果 $\mathrm{Cu} 19 \sim 85, \mathrm{~Pb} 59 \sim 69, \mathrm{Cd} 20 \sim 31, \mathrm{Fe} 58$ 〜73, Ca 30〜41, $\mathrm{Mg}$ 14〜17 ppm を含有していた。

第 3 期：高純度亜鉛は凹凸の激しい溶解性を呈し凹部 は白色生成物で埋まっていた。これに対し $\mathrm{VZ}+0.2 \mathrm{Al}$ は局部溶解の傾向があるが，付着物は白くて薄い。VZ+ $0.5 \mathrm{Al}$ は付着物皆無で溶解る均一であった。(写真 1 参照)

第 4 期：各種合金とも表面侸去しやすい白色付着 物が存在し溶解面は凹凸があった。 $\mathrm{Zn}+\mathrm{Al}$ の陽極は $\mathrm{VZ}+\mathrm{Al}$ のものに比し付着物がいくぶん多いが, 溶解 性注 いっ

そう

均一

で,

外観

上優

劣は

つけ

難い
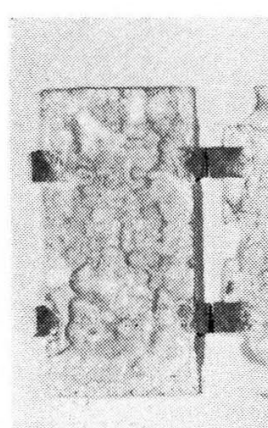

状沉

であった。

Zn

陽極が優良な性能を示した第 3 期と第 4 期とを比較す ると，船体電位がやや高いためか，第 3 期の方が一般に 付着物は少なく溶解性も均一であった。また第 3 期で理 想的な溶解状沉を示した $\mathrm{VZ}+0.5 \mathrm{Al}$ が，第 4 期ではい くぶん不均一な溶解を示し, 第 4 期では $\mathrm{Zn}+0.2 \mathrm{Al}$ が 最も均一な溶解性を示した。

第 3 表 陽極の平均溶解量および平均発生電流

\begin{tabular}{|c|c|c|c|c|c|c|}
\hline 期別 & 陽 極 種別 & $\begin{array}{l}\text { 使用 } \\
\text { 数 }\end{array}$ & $\begin{array}{l}\text { 平 均 } \\
\text { 溶 解 量 } \\
\text { kg }\end{array}$ & $\begin{array}{c}1 \text { 1個当 } \\
\text { 発生電流 } \\
\text { A }\end{array}$ & $\begin{array}{l}\text { 陽電流密度 } \\
\mathrm{A} / \mathrm{m}^{2}\end{array}$ & $\begin{array}{l}\text { 防電流密度 } \\
\mathrm{mA} / \mathrm{m}^{2}\end{array}$ \\
\hline 1 & Zn & 28 & 1.32 & 0.11 & 1.2 & 14.4 \\
\hline 2 & $\mathbf{Z n}_{\mathbf{n}}$ & 14 & 1.29 & 0.11 & 2.5 & 7.4 \\
\hline \multirow[t]{2}{*}{3} & $\begin{array}{c}\mathrm{Zn} \\
\mathrm{VZ}+0.2 \mathrm{Al} \\
\mathrm{VZ}+0.5 \mathrm{Al}\end{array}$ & $\begin{array}{l}8 \\
8 \\
8\end{array}$ & $\begin{array}{l}2.71 \\
2.46 \\
3.58\end{array}$ & $\begin{array}{l}0.24 \\
0.22 \\
0.32\end{array}$ & $\begin{array}{l}5.3 \\
4.9 \\
7.1\end{array}$ & \\
\hline & & 24 & 2.92 & 0.26 & 5.8 & 28.6 \\
\hline \multirow[t]{2}{*}{4} & $\begin{array}{l}\mathrm{VZ}+0.2 \mathrm{Al} \\
\mathrm{VZ}+0.5 \mathrm{Al} \\
\mathrm{Zn}+0.1 \mathrm{Al} \\
\mathrm{Zn}+0.2 \mathrm{Al} \\
\mathrm{Zn}+\mathrm{Cd}\end{array}$ & $\begin{array}{l}6 \\
5 \\
6 \\
5 \\
2 \\
\end{array}$ & $\begin{array}{l}2.16 \\
2.05 \\
2.17 \\
2.62 \\
1.81\end{array}$ & $\begin{array}{l}0.19 \\
0.18 \\
0.19 \\
0.23 \\
0.16\end{array}$ & $\begin{array}{l}4.2 \\
4.0 \\
4.2 \\
5.1 \\
3.6\end{array}$ & \\
\hline & & 24 & 2.21 & 0.19 & 4.2 & 20.9 \\
\hline
\end{tabular}

試験後の各陽極注生成物を除き水洗乾燥ののち 科 量 し，その減量に基ゔて発生電流を算定した。第 3 表に 各期における陽極種別ごとの溶解量と期間内の平均発生 電流を示す。ここで理論量は $\mathrm{Zn}$ が $0.82, \mathrm{Zn}+0.1 \mathrm{Al}$ が $0.822, \mathrm{Zn}+0.2 \mathrm{Al}$ が $0.824, \mathrm{Zn}+0.5 \mathrm{Al}$ が 0.831 (Ahr $/ \mathrm{g})$ ，また陽極効率は各種とも $90 \%$ と仮定した。

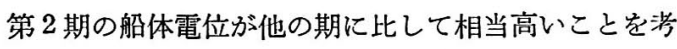
虑すると第 1 2 期の純亜鉛の発生電流密度が特に低い ことがわかるが，とれは $\mathrm{Fe}$ 分の比較的多い純严鉛を用 いたためと考光られる。良好な成績を示した第 3 期と第 4 期とを対比すると有効電位差の大きかった第 3 期の方 が溶解量（従って発生電流）は大きいが, 第 3 期におい ては $\mathrm{VZ}+0.5 \mathrm{Al}$ が卓越しており，第 4 期においては $\mathrm{Zn}+0.2 \mathrm{Al}$ が最良の結果を示した。

\section{4. 結}

小型船船を使用し 4 力年にわたり亜鉛陽極による外板 の防食試験を実施したが，その結果次の結論を得た。

（1）亜鉛の材質：陽極としては，高純度亜鉛よりも $0.2 \sim 0.5 \%$ の 1 を添加した亜鉛合金の方が性能がす ぐれている。すなわち高純度亜鉛陽極は使用中に生成物 が付着しやすく, 発生電流の低下を免れないのに対し, $\mathrm{Zn}-\mathrm{Al}$ 合金陽極では生成物は軟質ゼリ一状で付着し難い ので発生電流が維持される。しかしながら高純度亜鉛と 亜鉛合金のいずれについても高電流密度で作動させる方 が付着物が少なく, 溶解状況は改善される。

（2）亜鉛の装着量：本船の場合第 3 4 期試験にお ける装着量, 換言すれば船体外板の浸水面積 : 陽極総面 積の比率が 199 程度で優良な成績を示したから, 亜鉛合 金使用の場合 200 以上の比率で十分上認为られる。

（3）船底垐装: 本船は長年にわたりラジンベン系の $\mathrm{Al}$ および $\mathrm{AF}$ 叙料を厚く整り重ねたもので，亜鉛によ る相当低い電位に耐えたが，船体の一部に試験的に叙っ たビニル系塗装 (WP 使用) は一層良好な結果を示した。

(4) 船体電位と防食効果: 第 4 期試験のように分散 配置した合金亜鉛を使用すれば停止時においてきわ䚮て 均一な電位分布が得られた。また停止時の船体電位が防 食電位 $(-770 \mathrm{mV})$ 以下に保たれた場合は事実上発錆が 防止された。なお航走時の電位上昇は比較的僅少で第 4 期試験の場合 $7 \mathrm{kt}$ の航速で約 $20 \mathrm{mV}$ であった。

\section{付 記}

本試験の実施に当り絶大な御協力を頂いた元三池港務 所の技師長鈴木久之助，船渠課長兼田英一両氏はじめ関 倸者各位，亜鉛陽極等の資材を提供のう光種々御協力を 頂いた三井金属鉱業(株)製煉部の各位，並びに長期にわ たり困難な測定を担当された三池製煉所研究課の家吉課 長代理, 井上忠夫氏の各位に対し深甚の謝意学表する次 第である。 